\title{
DISTRIBUTION OF BLOOD GROUP IN BLOOD DONOR POPULATION IN WEST BENGAL
}

\author{
Arpita Chatterjee Halder ${ }^{1}$, Alpana De ${ }^{2}$, Saibendu Kumar Lahiri ${ }^{3}$
}

${ }_{1}^{1}$ Assistant Professor, Department of Anatomy, College of Medicine and Sagore Dutta Hospital, Kolkata, West Bengal, India.

2 Professor and HOD, Department of Anatomy, RG Kar Medical College and Hospital, Kolkata, West Bengal, India.

3Professor and HOD, Department of Community Medicine, RG Kar Medical College and Hospital, Kolkata, West Bengal, India.

\section{ABSTRACT}

\section{BACKGROUND}

The ABO blood group and Rh type is unique to every single individual. Prevalence of blood groups of all four types is different in various regions of this world.

Aim: The present study is intended to detect the prevalence of blood group among blood donors in West Bengal, the eastern state of India.

\section{MATERIALS AND METHODS}

Blood donors donating blood to Institute of Blood Transfusion Medicine and Immunohaematology (IBTMI), Kolkata, West Bengal are studied. Over 2 lac blood donors for more than 2 years are tested for blood group and Rh type. Donors are categorised according to sex and the prevalence of blood group is tested. Data collected by IBTMI is used as secondary data.

\section{RESULTS}

The study results show the prevalence of blood group in this region as $\mathrm{B}>0>\mathrm{A}>\mathrm{AB}$. The percentages of $\mathrm{B}+\mathrm{ve}, \mathrm{O}+\mathrm{ve}, \mathrm{A}+\mathrm{ve}$ and $\mathrm{AB}+\mathrm{ve}$ are $35.6 \%, 30.7 \%, 21.84 \%$ and $8.82 \%$. The prevalence of $\mathrm{Rh}$ negative type is $2.96 \%$ (average). These are found to be similar in both sexes.

\section{CONCLUSION}

As different parts of the world have different distribution of blood group, the distribution of blood group in this particular part of the country is determined. This improves our knowledge on prevalence of blood group in the region of the country we live in.

\section{KEY WORDS}

Donor Population, ABO Blood Group and Rh Type.

HOW TO CITE THIS ARTICLE: Halder AC, De A, Lahiri SK. Distribution of blood group in blood donor population in West Bengal. J. Evolution Med. Dent. Sci. 2018;7(31):3445-3447, DOI: 10.14260/jemds/2018/776

\section{BACKGROUND}

There are only 4 blood groups present all over the human race. Different blood groups vary in different populations, in different regions of the world. In this particular part of the world, the prevalence is found out targeting the blood donor population. The study was carried out with the following objectives-

1. To detect distribution of blood group and Rh type in the blood donor population of the specified area in West Bengal.

2. Distribution of blood group according to sex of blood donors.

\section{MATERIALS AND METHODS}

\section{(a) Study Area}

Institute of Blood Transfusion Medicine and Immunohaematology (IBTMI), Kolkata, Vivekananda Road, Kolkata-700006, West Bengal and its collection area.

\section{(b) Study Population}

Blood donors (18 - 60 years) donating blood in the camps organised by IBTMI and at IBTMI when in-house collection is arranged.

'Financial or Other Competing Interest': None.

Submission 22-06-2018, Peer Review 17-07-2018,

Acceptance 22-07-2018, Published 28-07-2018.

Corresponding Author:

Dr. Arpita Chatterjee Halder,

1/1f, Satin Sen Sarani, PO,

Kankurgachhi, Kolkata-700054, West Bengal, India.

E-mail: drarpitachat@ymail.com

DOI: $10.14260 /$ jemds $/ 2018 / 776$ (c) Study/ Data Collection Period

2007 to 2009.

\section{(d) Study Design}

Descriptive study data collected and recorded at IBTMI are used as secondary data. Individual blood bags are collected and numbered during blood collection.

\section{The Data are tabulated under the following Headings}

1. Blood Bag No.,

2. ABO group of Donor's Blood,

3. Rh type,

4. Sex of the Donor.

The results were worked out in an Excel worksheet and results were analysed.

\section{(e) Study Design}

Institutional Record-Based Retrospective Study. The collected data are studied for individual blood group and sex of the blood donor. Prevalence of blood group and Rh type in the study population is calculated. Distribution of blood group in either sex (male and female) is calculated.

\begin{tabular}{|c|c|c|c|}
\hline Blood Group & $\mathbf{2 0 0 7}$ & $\mathbf{2 0 0 8}$ & $\mathbf{2 0 0 9}$ \\
\hline A +ve & $\begin{array}{c}23281 \\
(21.86 \%)\end{array}$ & $\begin{array}{c}24997 \\
(21.88 \%)\end{array}$ & $\begin{array}{c}16934 \\
(21.97 \%)\end{array}$ \\
\hline A -ve & $791(0.74 \%)$ & $831(0.725)$ & $573(0.74 \%)$ \\
\hline B +ve & $\begin{array}{c}37836 \\
(35.54 \%)\end{array}$ & $\begin{array}{c}40624 \\
(0.72 \%)\end{array}$ & $\begin{array}{c}27429 \\
(35.59 \%)\end{array}$ \\
\hline B -ve & $\begin{array}{c}1199 \\
(1.12 \%)\end{array}$ & $\begin{array}{c}1206 \\
(35.56 \%)\end{array}$ & $\begin{array}{c}850 \\
(1.102 \%)\end{array}$ \\
\hline
\end{tabular}




\begin{tabular}{|c|c|c|c|}
\hline O +ve & $\begin{array}{c}32641 \\
(30.66 \%)\end{array}$ & $\begin{array}{c}35167 \\
(30.79 \%)\end{array}$ & $\begin{array}{c}23568 \\
(30.58 \%)\end{array}$ \\
\hline $\mathrm{O}$-ve & $1030(0.96 \%)$ & $988(0.86 \%)$ & $645(0.83 \%)$ \\
\hline $\mathrm{AB}+\mathrm{ve}$ & 9362 & 10072 & 6856 \\
& $(8.79 \%)$ & $(8.81 \%)$ & $(8.89 \%)$ \\
\hline $\mathrm{AB}-\mathrm{ve}$ & $311(0.29 \%)$ & $328(0.29 \%)$ & $206(0.26 \%)$ \\
\hline Oh +ve & 3 & 2 & 07 \\
& $(0.00003 \%)$ & $(0.00002 \%)$ & $(0.00009 \%)$ \\
Total & $\mathbf{1 0 6 4 5 4}$ & $\mathbf{1 1 4 2 1 5}$ & $\mathbf{7 7 0 6 8}$ \\
\hline
\end{tabular}

Table 1. Distribution of Blood Groups and Rh type in Blood Donors in the years 2007 to 2009

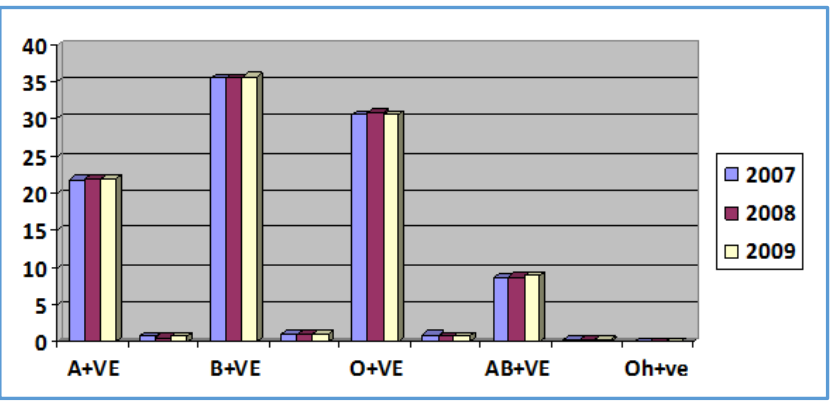

Figure 1. Distribution of Blood Groups and Rh Type in Blood Donors in the years 2007 to 2009

\begin{tabular}{|c|c|c|}
\hline $\begin{array}{l}\text { Blood Group and } \\
\text { Rh Type }\end{array}$ & $\begin{array}{l}\text { Total No. of } \\
\text { Donors }\end{array}$ & $\%$ \\
\hline$A+v e$ & 65,212 & $21.9 \%$ \\
\hline A -ve & 2,195 & $0.74 \%$ \\
\hline$B+v e$ & $1,05,889$ & $35.56 \%$ \\
\hline B -ve & 3,255 & $1.09 \%$ \\
\hline $\mathrm{O}+\mathrm{ve}$ & 91,376 & $30.69 \%$ \\
\hline 0 -ve & 2,663 & $0.89 \%$ \\
\hline$A B+v e$ & 26,290 & $8.83 \%$ \\
\hline$A B$-ve & 845 & $0.28 \%$ \\
\hline $\mathrm{Oh}+\mathrm{ve}$ & 12 & $\begin{array}{c}0.004 \% \\
\text { (negligible) }\end{array}$ \\
\hline Total & $2,97,737$ & \\
\hline \multicolumn{3}{|c|}{$\begin{array}{c}\text { Table 2. Distribution of Blood Group and Rh Type in Total } \\
\text { Number of Blood Donors }\end{array}$} \\
\hline
\end{tabular}

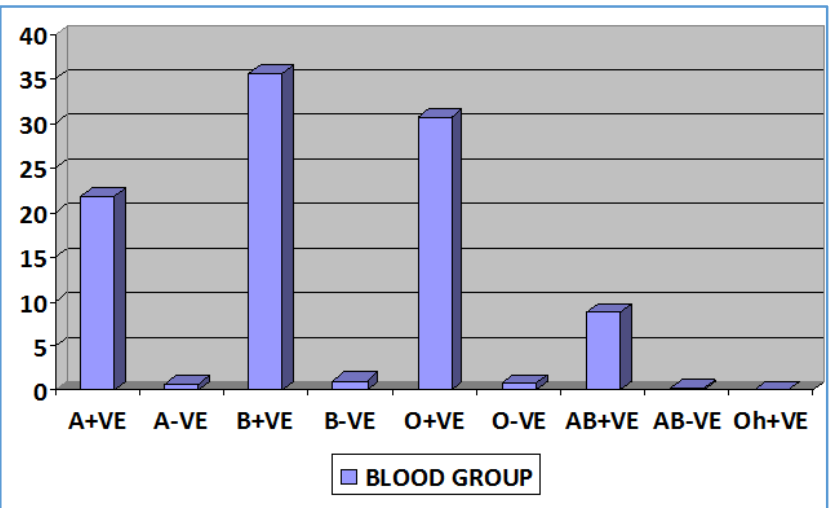

Figure 2. Percentage of Total Number of Blood Donors according to Blood Group

\begin{tabular}{|c|c|}
\hline $\mathrm{Rh}+\mathrm{ve}$ & $97.04 \%$ \\
\hline $\mathrm{Rh}-\mathrm{ve}$ & $2.96 \%$ \\
\hline Table 3. Distribution of Rh Type in Total Donor \\
Population
\end{tabular}

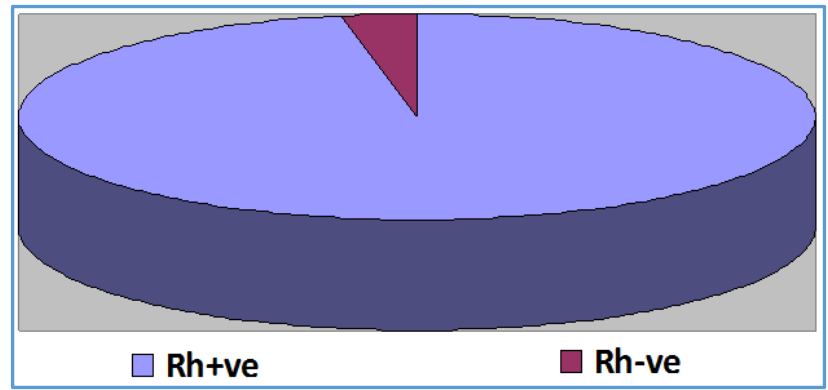

Figure 3. Distribution of Rh Type in Total Donor Population

\begin{tabular}{|c|c|c|c|c|}
\hline A +ve & $\begin{array}{c}\text { Male } \\
\text { Donors } \\
\mathbf{5 8 , 3 6 6}\end{array}$ & $\mathbf{2 1 . 9 \%}$ & $\begin{array}{c}\text { Female } \\
\text { Donors } \\
\mathbf{6 , 8 4 6}\end{array}$ & $\mathbf{2 1 . 9 1 \%}$ \\
\hline A -ve & 1,905 & $0.71 \%$ & 290 & $0.92 \%$ \\
\hline B +ve & 94,814 & $35.57 \%$ & 11,075 & $35.45 \%$ \\
\hline B -ve & 2,928 & $1.09 \%$ & 327 & $1.04 \%$ \\
\hline O +ve & 81,738 & $30.67 \%$ & 9,638 & $30.85 \%$ \\
\hline O -ve & 2,397 & $0.89 \%$ & 266 & $0.85 \%$ \\
\hline AB +ve & 23,581 & $8.85 \%$ & 2709 & $8.67 \%$ \\
\hline AB -ve & 766 & $0.29 \%$ & 79 & $0.25 \%$ \\
\hline $\begin{array}{c}\text { Oh +ve } \\
\text { Total }\end{array}$ & 6 & Negligible & 6 & Negligible \\
\hline Table & $2,66,501$ & Nitrib & \\
\hline
\end{tabular}

Table 4. Distribution of Blood Group and Rh Type in Male and Female Donors

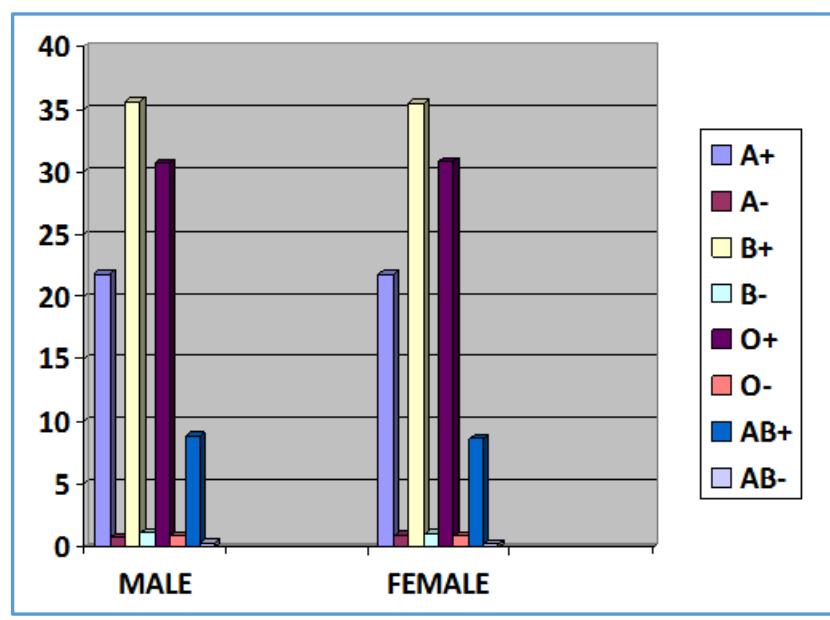

Figure 4. Distribution of Blood Group and Rh Type in Male and Female Donors

\section{RESULTS}

1. Distribution of ABO Blood Group and Rh type in Donor Population in the years 2007 - 09. During the study period from 2007 to 2009, amongst the blood donors, the most prevalent blood group was $B+v e$ followed by $0+v e, A+v e, A B+v e, B$-ve, 0 -ve, $A$-ve and $A B$-ve respectively (Table 1 and Figure 1 ).

2. Distribution of $\mathrm{ABO}$ blood $\mathrm{Rh}$ type in total donor population- Total donor population documented within the period of 2007 and 2009 is $(1,06,454+1,14,215+$ $77,068)=2,97,737$.

Distribution of blood group in the total population in the study period is similar (Table 2 and Figure 2).

3. Distribution of $\mathrm{Rh}+\mathrm{ve}$ donors and distribution of $\mathrm{Rh}$-ve donors in total time period is $2.96 \%$ and $\mathrm{Rh}+$ ve donors is $97.04 \%$ (Table 3 and Figure 3). 
4. The distribution of blood groups in males and females is similar in all different blood groups. Percentage of each blood group is calculated over total male donor population and total female donor population respectively. For example, B +ve blood group is found to be $35.6 \%$ in males and $35.48 \%$ in females (Table 4 and Figure 4).

\section{DISCUSSION}

The distribution of blood group varies from race to race. Amongst the western Europeans $46 \%$ belongs to Group 0, $42 \%$ belongs to Group A, 9\% to Group B and 3\% to Group AB. Some western Europeans show $40 \%$ of Group B amongst themselves. On the other hand some American Indians are exclusively Group 0.(1) In the American population, the frequency of $\mathrm{O}, \mathrm{A}, \mathrm{B}, \mathrm{AB}$ is $45 \%, 41 \%, 10 \%$ and $4 \%$.(2) $85 \%$ of white people are $\mathrm{Rh}$ positive, rest are $\mathrm{Rh}$ negative. $95 \%$ of American blacks are $\mathrm{Rh}+\mathrm{ve}$, whereas $100 \%$ of African blacks are $\mathrm{Rh}+$ ve.(3) Caucasians $85 \%$ are $\mathrm{Rh}$ positive, Asians 99\% are Rh positive.(2) Rahman $\mathrm{M}$ et al found that amongst a total 78,768 blood donors $(73,322$ that is $93.1 \%$ of them were male and 5446 that is $6.9 \%$ were females). $94.1 \%$ males were $\mathrm{Rh}$ positive and $91.9 \%$ of females were $\mathrm{Rh}$ positive. The frequency of blood groups $\mathrm{B}, \mathrm{O}, \mathrm{A}, \mathrm{AB}$ in Rhesus positive males were $32.4 \%, 30.5 \%, 22.6 \%$ and $8.6 \%$ respectively and in Rhesus positive females were $31.6 \%, 31.0 \%, 21.5 \%$ and $7.8 \%$ respectively. In Rhesus negative blood donors $0, \mathrm{~B}, \mathrm{~A}$ and $\mathrm{AB}$ blood groups were $2.22 \%, 1.85 \%, 1.46 \%$ and $0.39 \%$ in males and in females it was $3.13 \%, 2.74 \%, 1.76 \%$ and $0.51 \%$ respectively. Thus, it can be concluded the donor population is predominantly Rhesus positive. The order of frequency of blood groups in Rh positive donors is $\mathrm{B}, \mathrm{O}, \mathrm{A}$, $\mathrm{AB}$ and $\mathrm{Rh}$ negative donors $\mathrm{O}, \mathrm{A}, \mathrm{B}, \mathrm{AB}$ respectively.(4) Mathew Ebose Enosolease et al studied over twenty year period (1986 - 2005) a total of 160431 blood samples. These samples were grouped for $\mathrm{ABO}$ and Rh-D at the University of Benin Teaching Hospital, Benin City, Nigeria. Blood group distribution among these samples showed (phenotype) A, B, $\mathrm{AB}$ and $\mathrm{O}$ as $23.72 \%, 20.09 \%, 2.97 \%$ and $53.22 \%$ respectively. The Rh-D phenotype was found among 6.01\% of samples tested. Mohammed Anees et al in DHQ Hospital, Mandi, Bahauddin, Province of Punjab. The study conducted from January to December 2005 on 2542 subjects (2097 were male and 427 were female). The study revealed predominance of Group $\mathrm{B}$ in order of $\mathrm{B}>0>\mathrm{A}>\mathrm{AB}$ as well as Rh-positive antigen for male is 0.894 and in female it is 0.9039.(5) Tapas Pramanik et al concluded among 1310 Nepalese attending Tribhuvan University Teaching Hospital and Nepal Medical College, Kathmandu, the frequency of distribution of $\mathrm{O}, \mathrm{A}, \mathrm{B}$ and $\mathrm{AB}$ blood groups is $35.5 \%, 28.5 \%$, $27.3 \%$ and $8.7 \%$ respectively. Only $0.8 \%$ of them were found to be $\mathrm{Rh}$ negative. Ada $\mathrm{C}$ Kopec has commented that the distribution of $\mathrm{O}$ blood group gradually increases in frequency from south to north of Great Britain, whereas reverse is the case with blood group A.(6) Jorge Omar Morales et al - 95,562 individuals, resident of 6 districts of north-west Argentina. Amongst them 66\% belonged to 0 Group; $24 \%$ to Group A; $8 \%$ to Group B and only 2\% to Group AB.(7) Joshi SK et al found in his study population 0 +ve to be the most common blood group (31.9\%) followed by $\mathrm{A}+\mathrm{ve}, \mathrm{B}+\mathrm{ve}$ and $\mathrm{AB}+\mathrm{ve}$. (8)

Thus, this study helped us to detect the most prevalent blood group in blood donors of this region of the country.

\section{CONCLUSION}

In this study, blood donors donating blood at Institute of Blood Transfusion Medicine and Immunohaematology (IBTMI) are having their blood groups in the order of $\mathrm{B}+\mathrm{ve}>$ $\mathrm{O}+\mathrm{ve}>\mathrm{A}+\mathrm{ve}>\mathrm{AB}+\mathrm{ve}>\mathrm{B}-\mathrm{ve}>\mathrm{O}$-ve $>\mathrm{A}-\mathrm{ve}>\mathrm{AB}-\mathrm{ve}$ respectively. $97.04 \%$ of blood donors are $\mathrm{Rh}$ factor $+\mathrm{ve}$.

\section{ACKNOWLEDGMENT}

This study has been conducted under the guidance of Director and Deputy Director of IBTMI, Kolkata and the Department of Anatomy, RG Kar Medical College, Kolkata. I would like to thank the technical staff of IBTMI for their help during collection of data.

\section{REFERENCES}

[1] Keel CA, Neil E, Joels N. Blood groups. In: Samson Wright's applied physiology. $13^{\text {th }}$ edn. Oxford University Press 1996: p. 46.

[2] Ganong WF. Blood types. In: Review of medical physiology. 19th edn. Stanford, CT. USA: Appleton and Lange, A Simon and Schuster Co, 1999: p. 513-4.

[3] Guyton AC, Hall JE. Blood. In: Text book of medical physiology. 9th edn. USAWB Saunders Co., 1996: p. 458-9.

[4] Rehman M, Lodhi Y. Frequency of ABO \& Rhesus Blood Groups in blood donors of Punjab. Pak J Med Sci 2004;20(4):315-8.

[5] Anees M, Jawad A, Hashmi I. Distribution of ABO \& Rhesus Blood Group alleles in Mandi, Baharuddin district of Punjab, Pakistan. Proc Pakistan Acad Sci 2007;44(4):289-94.

[6] Kopec AC. Distribution of Blood Group in the United Kingdom: Monographs on Medical Genetics. Oxford University Press 1970.

[7] Morales JO, Dipierri JE, Alfaro EL, et al. Disribution of the ABO system in Argentine Northwest: Miscegenation and genetic diversity. Association Interciencia, Caracus, Venezuela 2000;25(009):432-5.

[8] Joshi SK, Ghimire GR. Serological prevalence of antibodies to Human Immunodeficiency Virus (HIV) and Hepatitis B Virus (HBV) among healthy Nepalese males-a retrospective study. Kathmandu Univ Med Journal 2003;1(4):251-5. 